\title{
The Role of Lean Manufacturing Practices in Greener Production: A Way to Reach Sustainability
}

\author{
Lokpriya Gaikwad $^{1}$, Vivek Sunnapwar ${ }^{2}$ \\ ${ }^{1}$ Mechanical Engineering Department, Sardar Patel College of Engineering, Mumbai, India \& SIES Graduate School of Technology, \\ Navi-Mumbai, India \\ ${ }^{2}$ Mechanical Engineering Department, Lokmanya Tilak College of Engineering, Navi-Mumbai, India
}

Email address:

lokpriya2007@gmail.com (L. Gaikwad),vivek.sunnapwar@gmail.com (V. Sunnapwar)

\section{To cite this article:}

Lokpriya Gaikwad, Vivek Sunnapwar. The Role of Lean Manufacturing Practices in Greener Production: A Way to Reach Sustainability. International Journal of Industrial and Manufacturing Systems Engineering. Special Issue: Manufacturing Strategy for Competitiveness. Vol. 5, No. 1, 2020, pp. 1-5. doi: 10.11648/j.ijimse.20200501.11

Received: January 7, 2020; Accepted: January 28, 2020; Published: February 13, 2020

\begin{abstract}
Due to globalization and competitive market, sustainability has increasingly gained importance to the manufacturing industry and Lean approaches are becoming more and more outstanding in order to improve operational and competitive performance. In addition, currently, firms have become more conscious of the fact that it is no longer adequate to take care of economic aspects, being crucial to take care of social and environmental aspects to succeed in the current and future markets. Lean manufacturing provides quality products at minimum cost to satisfy the customer. Aims of Lean manufacturing are to identify and eliminate the production process wastages for quality improvement, cost reduction, on-time delivery, i.e. to make efficient production processes to face the highest competition level, so lean is the latest tool to achieve it. While the aim of the Greener production is an environmental improvement of production processes by adopting best practices and seeking to eliminate waste and waste generation manufacturing processes. This research investigates how the Lean and Green practices and tools are being used for improvements in social, economic and environmental performance that directly affect overall business performance. The findings show that, a strong synergy linkingbetween Lean and Green and that a lot of Lean practices and tools can positively contribute to environmental sustainability which will help for both academicians and practitioners to take the advantage of their synergistic effects for achieving sustainable development in the manufacturing industry.
\end{abstract}

Keywords: Lean Manufacturing, Greener Production, Sustainability, Practices, Tools

\section{Introduction}

Currently, there is a need to create an environmentally conscious sustainable society which would help in fulfilling our present needs without affecting the future generation [1]. Organizations are constantly changing as per change in technology and management to meet the requirement of the customers, society, stakeholder and finally government. Thus reduction of impact generated due to manufacturing processes on the environment becomes an additional value to be added by firms. Pil and Maxwell [2], Yang Hong and Modi [3], have opined that the integration of Lean Manufacturing with environmental strategies could be a solution to eliminate wastages that are affecting the environment. The Lean concept creates an efficient operation and pulls together best practices such as Just-in-Time (JIT),
Total Quality Management (TQM), continuous improvement, resource planning, and supply chain management [4]. In literature, the term green manufacturing often used synonymously with the concept of sustainability.

Cleaner Production is a technique used for minimizing waste and environmental pollution $[5,6]$ while LM makes the manufacturing process more efficient while decreasing waste elimination in every production stage [7, 8]. Sarkisand Bergmiller $\&$ Mccright $[9,10]$ opined that the practices integrated into the organizational system for environmental protection can be determinant for reducing the environmental impact.

In this way, it becomes necessary to incorporate techniques or practices in the organizational system to reduce the environmental impact. Lean practices and tools can help control the use of resources in various stages of production $[11,12,13]$. Understanding the Lean and Greener/Cleaner 
relation is essential for organizations implementing these manufacturing systems since they can maximize their operational gains.

\section{Literature Survey}

The Lean system was originated at Toyota as the Toyota Production System and is known worldwide [14]. According to Womack and Jones [15] lean philosophy is to pursue using less of everything, which means to produce more with fewer resources while eliminating waste.

According to Yang et al. [3]; Bandehnezhad et al. [16] Lean improves environmental management practices that improve the environmental performance of processes and products [16, 17]. Shingo [19], Womack and Jones [20] opined that TPS is based on continuous improvement in production processes, seeking to eliminate unnecessary associated costs. The important definition of lean operational practices, Liker [14] and Womack and Jones [15] are presented in following table 1.

Table 1. Definition of Lean Manufacturing Operational Practices.

\begin{tabular}{|c|c|c|}
\hline Tools and Practices & Authors & Description \\
\hline Kaizen & Araujo; Rentes [21]; Imai [22] & $\begin{array}{l}\text { It is a continuous improvement practice of a process to add value and eliminate } \\
\text { wastages. }\end{array}$ \\
\hline 5'S' & Feld [23]; Lean Enterprise Institute [24] & It is a practice for improving working environment. \\
\hline Value Stream Mapping & Rother; Shook [25] & $\begin{array}{l}\text { It is lean tools which study the current state of process and make improvement } \\
\text { in it. }\end{array}$ \\
\hline Standardized Work & Lean Enterprise Institute [24]. & It is a standard procedure for each employee's work in a production process. \\
\hline JIT & Shingo [26]; Lean Enterprise Institute [24] & $\begin{array}{l}\text { JIT control inventory so that everything is produced in required quantity at right } \\
\text { time and right place when needed. }\end{array}$ \\
\hline Kanban & $\begin{array}{l}\text { Ohno [27]; Feld [23]; } \\
\text { Lean Enterprise Institute [24] }\end{array}$ & $\begin{array}{l}\text { Kanbanis a Lean tool that works as a customer demand signal, i.e., authorizing } \\
\text { the start of production or removal of items in a working system. It also controls } \\
\text { the level of work in process. }\end{array}$ \\
\hline SMED & Feld [23] & Aims to reduce the setup time, known as Quick Change die set. \\
\hline Manufacturing cells & Lean Enterprise Institute [24]; Black [28] & $\begin{array}{l}\text { Involves the workstations producing similar products in a sequence and in } \\
\text { continuous flow. }\end{array}$ \\
\hline TPM & Feld [23]; Lean Enterprise Institute [24] & $\begin{array}{l}\text { Aims to ensure the reliability and overall productivity of equipments, involving } \\
\text { all employees of the organization. }\end{array}$ \\
\hline Heijunka & Hüttmeir et al. [29] & Production capacity is kept constant under many issues.. \\
\hline Ishikawa Diagram & Ishikawa \& Loftus [30] & $\begin{array}{l}\text { It is a graphical representation that illustrates relationships between a specific } \\
\text { result and its causes. }\end{array}$ \\
\hline Water spider & Womack \& Jones [7] & Rapid and efficient movement to collect and deliver materials. \\
\hline Poka yoke & Feld [23]; Lean Enterprise Institute [24] & Mistakes proofing tool. \\
\hline $\mathrm{VM}$ & Lean Enterprise Institute [24] & $\begin{array}{l}\text { Measurement of system activities and performance indicators so that workers } \\
\text { can quickly understand the system status. }\end{array}$ \\
\hline $\begin{array}{l}\text { Autonomous } \\
\text { Inspection }\end{array}$ & Swanson [31] & $\begin{array}{l}\text { Machine Performance improvement through communication which causes } \\
\text { elimination of possible failures and problems with the equipment in their } \\
\text { inspection. }\end{array}$ \\
\hline
\end{tabular}

\section{Methodology}

A literature review was conducted to analyze the relationship between operational practices of Lean manufacturing and reduction of environmental impact in organizational contexts. The procedure to perform the literature review was based on the use of databases to find peer-reviewed journal articles that contained at least a keyword related to both, Lean and Green/Clean manufacturing. The search results showed that 42 articles from 1986 to 2017 have been published to address the connection between Lean and Green/Clean, with the majority being published in the last 10 years. The information was examined qualitatively considering the technique for content analysis and to find out the relationship between them.

\section{Greener Production}

In the search for sustainability, different approaches have come out to deal with industries' environmental impacts. In the year the 1960s and 1970s efforts have been taken for the regulation of industrial activities which objective was reducingimpacts of manufacturing on the environment. According to OECD (organization for economic co-operation and development), greener technologies pull out and use natural resources as capably as possibly in all stages that generate harmless products for the society which minimize releases to air, water and soil during production and after its life cycle thatproduct can be recovered or recycled.

Greener production reduces cost while improving process efficiencies, whereas investment in cleaner production is low for replacing existing systems or equipment. "Green" product is the product that must be manufactured as per environmental legislation. Greener Production and Pollution Prevention have the same goal: continuous reduction of pollution and eliminating environmental waste in the process. The main concern of the greener production is to create responsiveness for the prevention of pollution and to find the source of wastes and emissions generation by implementing and documenting Greener production strategy. Greener 
production's driver is to reduce the costs associated with environmental waste, besides the reduction of environmental impacts.

\section{Lean and Greener Production}

While reducing environmental waste and increasing productivity is necessary for all industries which are possible by using Lean with Greener production [32]. Song and Liang [33] opined that while Lean concentrates on improving cost and time performance and can bring immediate economic value, environmental sustainability is considered a different aspect of value, which is related to reducing environmental impacts. They also state the gain of Greener production with Lean through the elimination of waste by providing the concept of "Free Green". Sawhneyet. al [34] determined that lean focus on systematic waste elimination with ecological protection. According to Song and Liang [33], the environmentally sustainable outlook, Lean can result in environmental impacts that vary in type and magnitude reinforcing the perception that the combined implementation of the two concepts can be often argumentative. Lapinski et al. [35] applied an interesting approach to make use of Lean concepts and tools and add to Lean customer values a value related to environmental impacts. Other than the value related to cost, time and quality desired, other factors are included in the customer value, such as environmental occupation, environmental performance, and minimal environmental impact, among others; at the same time that environmental waste is defined as waste.

The concept of "value" in the Lean theory should be associated with sustainability to ensure a win-win association between Lean and GP [33]. Dues et al. [36] analyzed both concepts and provided evidence of the areas where lean and green overlap. Both practices are beneficial having a positive influence on existing Lean business practices. A generalization of their findings is presented in Figure 1, where both concepts overlap on creating value for the customer and improving waste elimination to achieve business success.

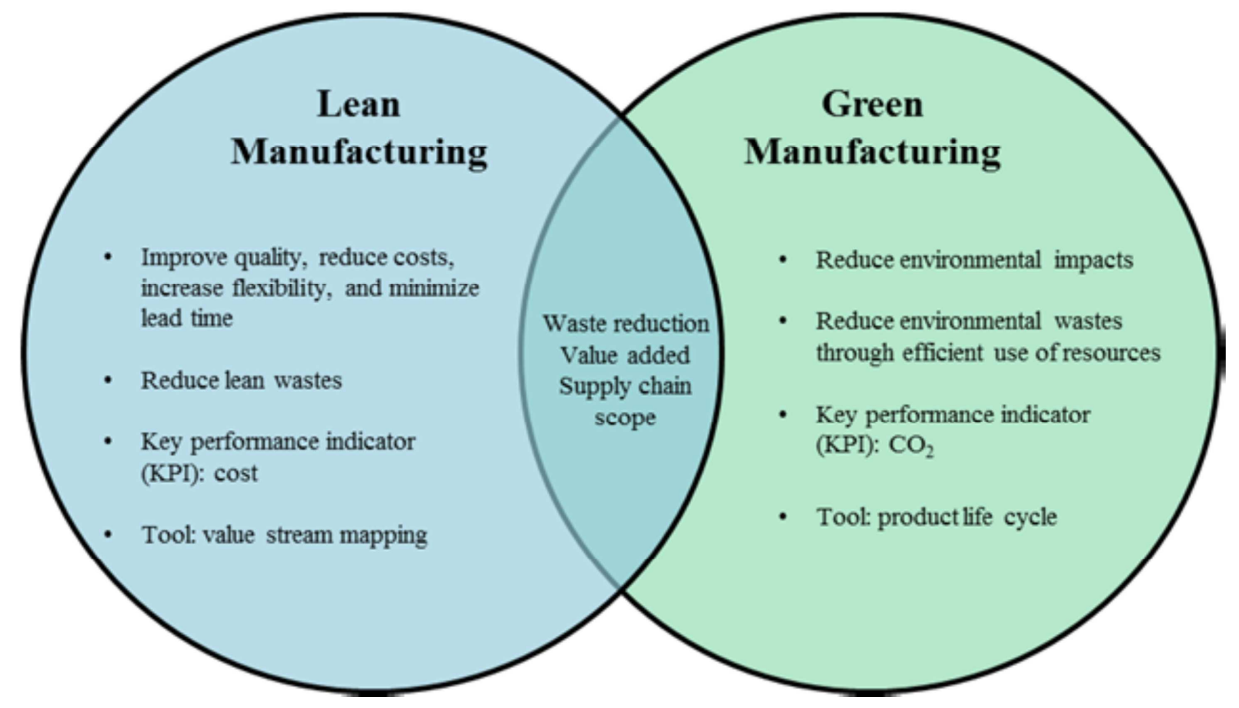

Figure 1. Lean and Green philosophies [36].

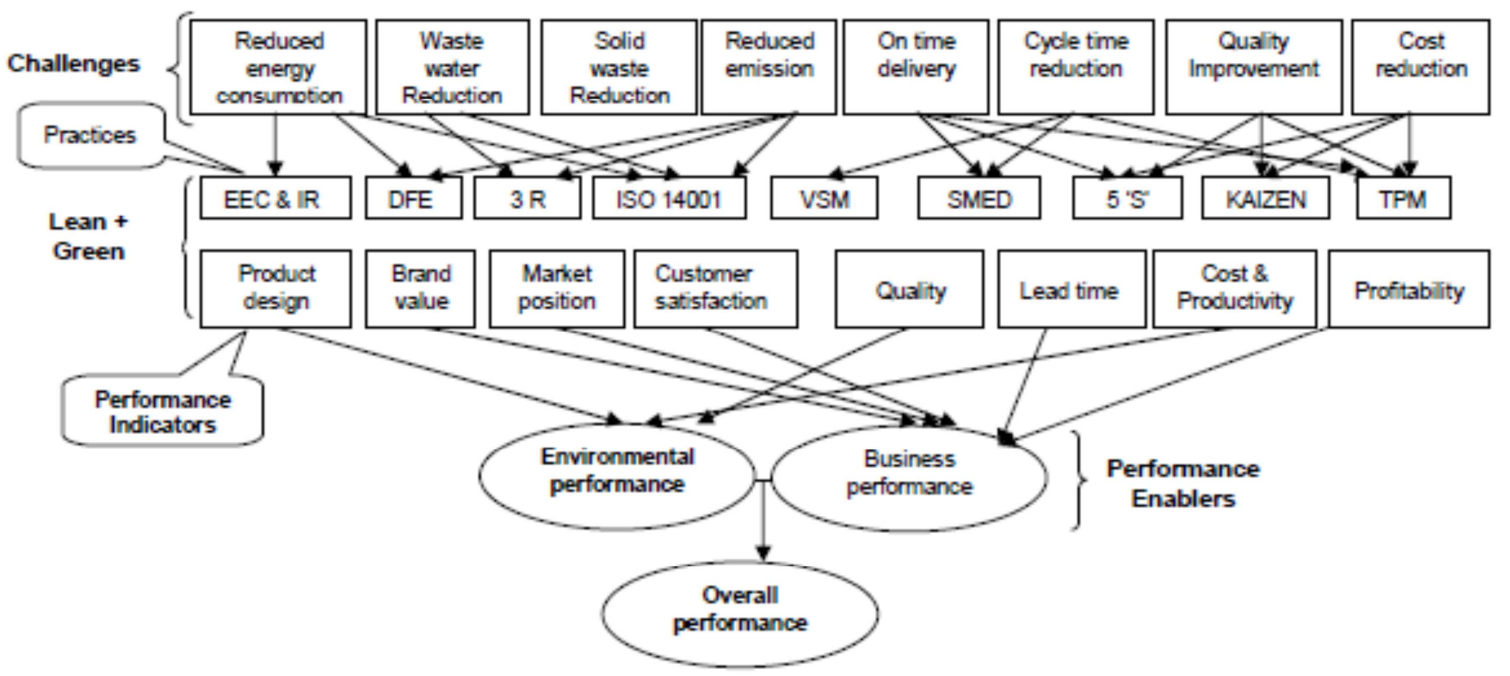

Figure 2. Integrated model for tools, methods and techniques of Lean-Green system [37]. 
Xiaoyong Zhu et al. [37] presented an integrated model as shown in figure 2 for tools, methods and techniques of lean green system to improve the overall operational performance of the manufacturing industry. The main challenges faced by the organization now a days are cost reduction, quality improvement, customer satisfaction, on time delivery, cycle time reduction, waste reduction, resources conservation etc. which need to implement lean practices such as TPM, VSM, JIT, KANBAN, 5S, KAIZEN, SMED etc. together with some green practices like 3R, EMS 14001, EEC \& IR which will enhance the business and environmental performance of the organization.

\section{Results}

In this section the information extracted from the 42 literatures, selected are going to be described in order to identify which and how Lean Manufacturing tools can be used in Greener Production in order to promote environmental improvements. It was found that there is evidence for the existence of relationship between the practices of Lean manufacturing and their effect on environment. This reduction was observed after implementation of these practices that resulted in the reduction of energy and water consumption and at the same time proper resource utilization. Galeazzo et al. [38] in a research work also opined that there is interdependency between Lean and Green practices which may be implemented either sequentially or simultaneously.

Johansson and Sundin [39] demonstrate that from a Lean perspective, when a waste is minimized; it provides benefits from a sustainability perspective since inefficiencies lead to increased environmental burdens with this support, Upadhye et al. [40] states that Lean manufacturing systems provide a competitive strategy to achieve sustainability.

Soltero and Waldrip [41] found that Lean manufacturing provides the organization with the tools and techniques to attain its pollution prevention goals. Most of the authors have suggested that when an organization achieves sustainable improvements in a Lean production system, they may create a competitive advantage [42].

\section{Conclusion}

No. of Lean Manufacturing tools can be used for obtaining environmental benefits, such as cleaner greener production which is environmental conscious type of manufacturing process. The method utilized helped to identify some practices that favour of lean environmental performance. However, it is not possible to generalize the results because of limited reviews of articles were analyzed, among which only the outcomes of the success stories were presented. For a better understanding of the study subject, it is suggested that further studies are conducted, to quantitatively evaluate the environmental benefits achieved through the accomplishment of lean tools and techniques to promote the cleaner production of a manufacturing industry.

\section{References}

[1] Angell L. C., and H. S. Lewis. (1999) 'Environmental and Operations Management Face the Future Decision Line'. Pennsylvania.

[2] Pil, F., Rothenberg and Maxwell, J. (2001) "Lean, green, and the quest for superior environmental performance," Prod. Operation Management, vol. 10, no. 3, pp. 228-243.

[3] Yang, M. G., Hong, P., \& Modi, S. B. (2011) 'Impact of lean manufacturing and environmental management on business performance: an empirical study of manufacturing firms'. International Journal of Production Economics, 128 (2), 251261. http://doi.org/10.1016/j.ijpe.2010.10.017.

[4] Oduoza, C. F. (2008) 'Lean thinking constrains in traditional batch manufacturing environments', Advances in production Engineering and Management Journal, Vol. 3, No. 4, pp. 181192.

[5] Frijns J., and B. V. Vliet. (1999) 'Small-Scale Industry and Cleaner Production Strategies'. World Development, Vol. 27, No. 6, pp. 967-983.

[6] Bradbury H. (2003) 'Sustaining Inner and Outer Worlds: A Whole-Systems Approach to Developing Sustainable Business Practices in Management'. J. Mngmt. Edu., Vol. 27 (2), pp. 172-187.

[7] Womack J., D. Jones, and D. Roos. (1991) 'The machine that changed the world: The story of lean production'. Harper Perennial, New York.

[8] Mohamad E., and M. A. Sulaiman. (2016) 'Simulation-based approach to Lean Manufacturing'. Penerbit Universiti, Universiti Teknikal Malaysia Melaka.

[9] Sarkis, J. (2003). A strategic decision making framework for green supply chain management. Journal of Cleaner Production, 11 (4), 397-409.

[10] Bergmiller, G. G., \& Mc Cright, P. R. (2009) 'Parallel models for lean and green operations', In Proceedings of the 2009 Industrial Engineering Research Conference.

[11] Zhang, L., Zhan, Y., Liu, Z. F., Zhang, H. C., \& Li, B. B. (2011) 'Development and analysis of design for environment oriented design parameters'. Journal of Cleaner Production, 19 (15), 1723-1733.

[12] Chiang, T. A., \& Roy, R. (2012) 'An intelligent benchmarkbased design for environment system for derivative eletronic product development'. Computers in Industry, 63, 913- 929.

[13] Fiksel, J. (2009) 'Design for Environment: A Guide to Sustainable Product Development (2. ed.)'. New York: McGraw Hill.

[14] Liker, Jeffrey and Meier, David. The Toyota Way Fieldbook. US: McGraw-Hill, 2005.

[15] Womack, J. P., \& Jones, D. T. (2003). Lean thinking: Banish waste and create wealth in your corporation New York: Free Press. 
[16] Bandehnezhad, M., Zailani, S., \& Fernando, Y. (2012) 'An empirical study on the contribution of lean practices to environmental performance of the manufacturing firm in northern region of Malaysia'. International Journal of Value Chain Management, 6 (2), 144-168.

[17] Matos, S., \& Hall, J. (2007) 'Integrating sustainable development in the supply chain: the case of sustainable development in the oil and gas and agricultural biotechnology'. Journal of Operations Management, 25 (6), 1083-1102.

[18] Miettinem, P., \& Hamalainen, R. P. (1997). How to benefit from decision analysis in environmental life cycle assessment (LCA). European Journal of of Operational Research, 102 (2), 279-294.

[19] Shingo, S. (1988) 'Zero quality control: source inspection and the poka-yoke system'. Productivity Press.

[20] Womack, J. P., \& Jones, D. T. (1998) 'The Lean Thinking in Business (4 ed.)’. Rio de Janeiro: Campus.

[21] Araujo, C. A. C.; Rentes, A. F. A Metodologia Kaizen nacondução de processos de mudançaemsistemas de Produção Enxuta. In: Revista Gestão Industrial. v. 02, n. 02: p. 126-135, 2006.

[22] Imai, M. (1986) 'Kaizen: The Key to Japan's Competitive Success'. New York: Random House.

[23] Feld, W. M. (2000) 'Lean Manufacturing: tools, techniques and how to use them'. Boca Raton: St. Lucie Press, 228 p.

[24] Lean Enterprise Institute. (2003). Léxico Lean: Glossárioilustradoparapraticantes do pensamento lean. São Paulo: Lean Institute Brasil, vol. 1, 97, p.,

[25] Rother, M.; Shook, J. (1999) 'Aprendendo a enxergar: mapeando o fluxo de valorpara agregarvalor e eliminar o desperdício'. São Paulo: Lean Institute Brasil, v. 1.2, 100 p.

[26] Shingo, S. (1996) 'The Toyota Production System'. Porto Alegre: Bookman, p. 292.

[27] Ohno, T. O sistema (1997) 'Toyota de produção: além da produçãoemlargaescala.' Porto Alegre: Bookman, 149 p.

[28] Black, J. T. (1991). 'The Design of the Factory with a Future, McGraw-Hill.

[29] Hüttmeir, A., Treville, S., Ackere, A. V., Monnier, L., \& Prenninger, J. (2009) 'Trading off between heijunka and Justin-sequence'. International Journal of Production Economics, 118 (2), 501-507.

[30] Ishikawa K, Loftus JH, (Eds): Introduction to quality control. 1990, Tokyo, Japan: 3A Corporation.
[31] Swanson, L. (2001) 'Linking maintenance strategies to performance'. International Journal of Production Economics, 70 (3), 237-244.

[32] Parveen, C. M.; Kumar, A. R. P.; Rao, T. V. V. L. N. (2011) 'Integration of Lean and Green Supply Chain - Impact On Manufacturing Firms In Improving Environmental Efficiencies'. In: International Conference on Green Technology and Environmental Conservation (GTEC 2011).

[33] Song, L.; Liang, D. (2011) 'Lean construction implementation and its implication on sustainability: a contractor's case study'. In: Canadian Journal of Civil Engineering, vol. 38, no. 3, p. 350-359.

[34] Sawhney, R.; Teparakul, P.; Aruna, B.; Li, X. (2007) 'lean: a framework to align lean and green manufacturing in the metal cutting supply chain.' In: International Journal of Enterprise Network Management, vol. 1, no. 3, p. 238-260.

[35] Lapinski, A. R.; Horman, M. J.; Riley, D. R.(2007) 'Lean Processes for Sustainable Project Delivery. In: Journal of Construction Engineering and Management, Vol. 132, No. 10, p. $1083-1091$.

[36] Dues, C. M., Tan, K.-H., Lim, M., (2013). Green as the new lean: how to use Lean practices as a catalyst to greening your supply chain. J. Clean. Prod. 40, 93-100.

[37] Xiaoyong Zhu; Hua Zhang; Chao Wu; Zhe Huang (2017). 'An Economic Model of Integration Framework of Lean Production and Green Manufacturing Based on Sustainability Balanced Scorecard.' Boletín Técnico, Vol. 55, Issue 12, pp. 263-269.

[38] Galeazzo, A. Furlan and A. Vinelli. (2014) 'Lean and Green in action: interdependencies and performance of pollution prevention projects', Journal of Cleaner Production, vol. 85, pp. 191-200.

[39] Johansson G. and E. Sundin. (2014) 'Lean and Green product development: two sides of the same coin?', Journal of Cleaner Production, vol. 85, pp. 104-121.

[40] Upadhye N., S. G. Deshmukh and S. Garg. (2010) 'Lean manufacturing for sustainable development', Global Business and Management Research: An Intenational Jourmal, vol. 2, no. 1 , pp. 125.

[41] Soltero C. and G. Waldrip. (2002) 'Using kaizen to reduce waste and prevent pollution', Environmental Quality Management, vol. 11, no. 3, pp. 23- 38.

[42] Maxwell J., F. Briscoe, B. Schenk and S. Rothenberg. (1998) 'Case study: Honda of America Manufacturing, Inc.: Can Lean production practices increase environmental performance?', Environmental Quality Management, vol. 8, no. 1, pp. 53-61. 